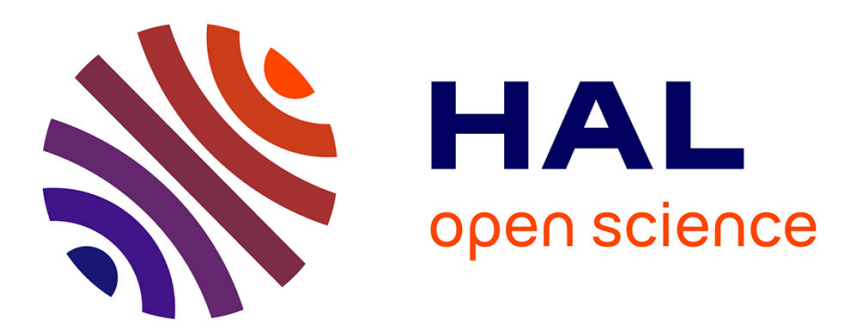

\title{
STUDY OF RESIDUAL STRESSES INDUCED BY LASER-SHOCKS
}

P. Ballard, J. Fournier, R. Fabbro

\section{To cite this version:}

P. Ballard, J. Fournier, R. Fabbro. STUDY OF RESIDUAL STRESSES INDUCED BY LASER-SHOCKS. Journal de Physique IV Proceedings, 1991, 01 (C7), pp.C7-132-C7-132. 10.1051/jp4:1991728 . jpa-00250931

\section{HAL Id: jpa-00250931 https://hal.science/jpa-00250931}

Submitted on 1 Jan 1991

HAL is a multi-disciplinary open access archive for the deposit and dissemination of scientific research documents, whether they are published or not. The documents may come from teaching and research institutions in France or abroad, or from public or private research centers.
L'archive ouverte pluridisciplinaire HAL, est destinée au dépôt et à la diffusion de documents scientifiques de niveau recherche, publiés ou non, émanant des établissements d'enseignement et de recherche français ou étrangers, des laboratoires publics ou privés. 


\section{STUDY OF RESIDUAL STRESSES INDUCED BY LASER-SHOCKS}

P. BALLARD, J. FOURNIER and R. FABBRO*

PSA Etudes \& Recherches, $F$-78140 Vélizy, France

*Laboratoire d'Application des Lasers de Puissance (Unité mixte ETCA/CNRS), 16 av. Prieur de la Côte d'Or, F-94114 Arcueil, France

When a metallic target is irradiated with a short intense laser pulse, a high pressure plasma is generated at the surface of the target.

We present first some plasma pressure measurements. These measurements are made by mean of a piezoelectric quartz gauges and are temporally resolved. Laser pulse duration is ranging from 0.6 to 100 nanoseconds and intensity from 1 to $100 \mathrm{GW} / \mathrm{cm}^{2}$, giving peak pressures in the 10 to 50 kbars range.

The propagation of the plastic wave induced in the target is analytically and numerically studied. It appears that a monodimensional analysis is justified. The influence of strain-hardening, viscosity, etc... is analysed. The plastic strain field is calculated and its evolution when laser parameters are varying is discussed.

Then a bidimensional elastic analysis allows to predict the whole residual stresses field. The influence of the material parameters and geometry are discussed.

These calculation results are compared to systematical residual stresses measurements by mean of X-Ray diffraction.

Lastly, the application of this work is the development of a new surface treatment able to improve the fatigue behaviour of materials. Some fatigue test results are presented. Comparisons with fatigue improvement obtained by a traditional process such as shot-peening show the great interest of this new treatment. 